\title{
社会参加の場としての里山
}

\section{Coppice Woodlands on Social Activities}

重松 敏則*

Toshinori SHIGEMATSU

\section{1.はじめに}

私達の心の原風景は里山・田園風景と言われるが, それ は人口の過半数が農山村に居住し, 都市規模も限られたつ い30 40 年ほど前まで, 多くの子供達の生活環境, 遊び の環境は, 里山や田園だったからであり, そこでの自然遊 びを通して, 自然に対する好奇心や振るまい方, 創造力や 協調心，伝統文化に対するイメージや情感の共有などが育 まれたといってよい。

しかし, 戦後の都市への人口集中と都市膨張によって, 多くの都市住民は緑の乏しい生活環境の中で, 地域に無関 心な流民社会を形成しており，世代交代が進むなかで故郷 の農山村とのきづなも失われつつある。さらに都市的ライ フスタイルの偏重によって, 都市住民の季節感は次第に鈍 感になっており, 里山の情景や遊山の楽しさを知らない子 供達は，もはや童謡やおとぎ話に感動したり，イメージを 共有することもなく, また青少年や市民はボーダレスな情 報ラッシュの中で, 使い捨ての消費生活を送っている実情 にある。今や多くの国民の文化的アイデンティティと連帯 感は, 希薄なものになっているのである。

一方, 里山・田園地域の自然環境や文化景観の保全には, 国土保全や食料の安全保障をあ視野に入れ，その意義を認 識した管理の担い手，ならびに社会的支援が必要である。 また, 地球環境危機の時代に直面して，その解決の鍵を握 る「自然の生態系に対する認識を有し，地球的視野での参 加と連帯のライフスタイルを持った人づくり」のためのシ ステム形成も, 重要な今日的課題である。

\section{2. 市民参加による里山管理の効果}

このようなとき，市民参加による管理活動には，大きな 効果が期待できる。森林管理といえばハードな肉体労働と 考えられがちだが, 余暇活動やボランティア活動として気 軽に取り組めば，楽しくてやり甲斐があり，思わず熱中し てしまうことが，多くの実践事例から明らかとなってい

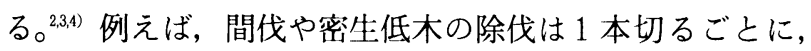

林地が明るく開放的となるため，また 1 本また 1 本と夢中 になってしまうのである。昔の郷愁に浸る老人, 友達に誘 われ半信半疑で参加してすっかり“とりこ”になった OL, 木を切ることの面白さに夢中になる小学生など, 市民が里 山管理に参加することを通して, 活動の楽しさや里山の自 然の素晴らしさを発見し, 絶妙な生態のシステムやバラン スを認識する。こうして里山の原風景や野生動植物の生存 環境の復元にかかわるなかで，自らも育まれていくのである。

里山管理にしろ, 棚田の石積みにしろ, 市民が活動に参 加することをきっかけに，それまでの単なる“山の緑” や“石坦”をより細部にわたり，こだわりをもって見 るようになる。また，現場活動を通して得られる充実感や， 未知の人と連帯する喜びを体感するようになり，これは工 業化社会ならびに高路化社会における健康づくりや生きが い,コミュニケーションづくりの上であ大いに意義がある。

緑の乏しい都市環境に居住する都市住民の中には，心に 故郷の原風景をいだきながら，何とか里山や田園で活動し たいと願う人々がいるが，それを実現する機会やシステム がないため，多数を占める流民社会の中に埋没しているに 過ぎない。決して少数ではないこれらの人々の “思い” や参加意欲を引き出せば，農林業者と交流・協力しながら 伝統的な風土景観を保全し，加里山や田園に共生する動 植物を復活させるという，楽しく，希望のある活動を通し て，「人づくり」を進めることが期待できる。これは，認 識をもった「生活者」として今後の安全で快適な都市づく り, すなわち美しく未来に希望の持てる, 定住型の生活環 境づくりの担い手を養成することにも通じょう。

\section{3. 保全活動システムの形成}

（1）市民活動の発達段階

里山・田園環境の保全活動をべースとした，市民参加シ ステムを構築する上で，まずそれをどのように起動するか が問題となる。たとえ小規模でも既に自主的な地域活動が 存在すれば，行政や企業が積極的に支援し，より充実した

*九州芸術工科大学芸術工学部 
活動組織体に育成すればよい。しかし，未だ存在しない場 合や，存在しても地域の行政当局が評価していなかったり， 相互に反目しあっていたりすることも多い。

一方, 行政当局が市民参加による保全活動の重要性を認 識し, 自らの施策として市民参加を募り, 活動事業を運営 したとするなら，それはそれで意義があり効果があること は言うまであない。しかし，このような官製のボランティ ア活動は奉仕義務的なイメージが拭いきれないため, 市民 から敬遠されがちな上に，行政の枠組みの中での担当職員 の配置や運営では, 経験や技術手法が蓄積されにくく, ま た柔軟な活動の展開や組織の発展におのずと限界があると いう問題がある。では, どのように自主的な地域活動を起 こし，それを発展させれば良いのであろうか。

地域により実情の異なる市民活動の有無やその発達段階 を分類すると，以下のように区分できる。

(1)休眠期：地域住民・行政ともに認識なし

(2)萌芽期： 地域住民, 行政のいずれかが認識 活動を開始するが交流なし

(3)発展期： 地域住民が組織的活動を行ない, 地域行政む対応しだす

(4)完成期： 地域住民が組織活動を展開する 地域行政が積極的に連携・支援

既に(3)の段階であれば, あとは地域の市民活動団体と行 政のパートナーシップにより, 活動内容をどれだけ充実し, 活動範囲や動員力を展開するかである。問題は(1)や(2)の場 合である。特に地域に何ら活動の芽がない場合には, 外部 からの刺激によって認識を呼び覚ます必要がある。

（2）情報伝達による地域活動の触発

都市では市民す行政す, 図 1 の(1)動機づけに示すような 問題に直面しており，農山村でも多くの課題を抱えている。 そして，それぞれに問題解決の必要性を感じ，支援や協力 を期待しているのである。しかし, 農山村と都市の住民, また行政の間には認識に大きなずれがあり, 一方で希望していることを他方では思いもつ かなかったり, 疑念が先だって対応や呼びか けを躊躇し，相互の意思疎通や交流が進展し ない実情にある。例えば，都市住民が下刈り・ 間伐等の森林管理や, 棚田の石積み修復等の 田園保全に参加したいと願っていても，農山 村側は「そのような肉体労働を, 都市住民が 好き好んでするはずがない」と思い込んでい る。また，農山村側は都市住民を「ゴミを捨 てたり，好き勝手に山菜採りをする無作法者」 と敵視しがちであるが, 都市住民の中には里 山や田園の自然を大切に思い, その保全・管 理に協力したいと願う人々が少なくない。一 方，都市住民も「農山村住民は排他的，閉鎖

(1)動機づけ

(2)共鳴・協力

(3)システム形成

的」と考えがちだが，都市住民の支援を期待したり，積極 的に交流したいと望む農林業家も多数いるのである。

このような都市と農山村の認識のずれを是正したり, 地 域の潜在的な参加欲求や活動に対する情熱を発掘するには, 外部からの刺激により地域活動を触発し, 実践的な行動や 成果を示す必要がある。これまでの調査結果から，それに はまず環境問題及び市民参加をテーマとする講演会や学習 会を実施し，具体的で実践的な情報を提供するのが有効で あることが明らかとなっている。 ${ }^{2,344}$ この場合, 予備知識の ない人にも一連の問題点が容易に理解でき, 自分達が行動 をおこせば, 様々な問題が次々と解決する道が開ける, とい う希望や情熱を引き出すことが重要である。それには，言 葉だけでの解説には自ずと限界があり, 実際の映像で視覚 的に示しながら解説すると, その理解度は飛躍的に高まる。 （3）キイパーソンの発掘と地域活動の展開

一方, 地域活動を生み出し, 活動を展開するには情熱を もったキイパーソンの存在が不可欠である。人間社会には 一見何むないように見える所でも，意外に多様な意識や情 熱，技術経験をむった人が潜んでいるあのであり，このよ うな人材をいかに引き出し, 活かすかが重要である。講演 会や学習会の後にこれらの人々に協力を呼びかけて, まず, 少人数の活動グループを結成する。

次いで，実践的な活動経験と実績を積むために，11自然 観察会・実習会や，(2)里山林の下刈り・間伐実習，などを 行う。現代社会では,こうした体験学習の呼びかけは人々 を引きつけ，自然のしくみやかつての農山村の有機的な生 活の営みを，作業体験を通して実感するきっかけを与える。 事例調查でも，このような催しを機会に，かつての農山村 生活の思い出をむった人々が集まり，また初めての体験者 もこれまで知らなかった楽しみの世界を発見し，好奇心や 情熱を触発されて，その後む継続的に集うょうになる。こ うして市民活動のけん引者となるキイパーソンや情熱をもっ

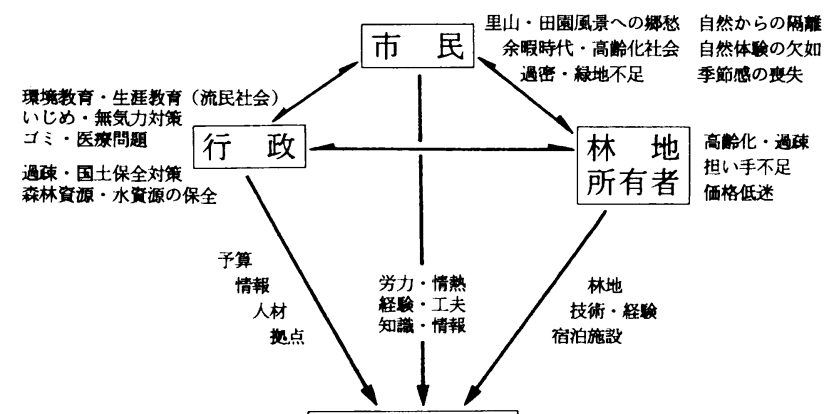

(4)活動の展開 と運営

図ー1森林保全のための市民参加システム形成のプロセス 
た人材が集まると, これらの人々を核に, より強力な活動 組織が結成されることも明らかとなっている。 合, BTCV(British Trust for Conservation Volunteers )$^{5)}$ のような国外の活動団体との連携による，国際保全合 宿(International Conservation Working Holidays)のよ うな活動交流を行うと, 地域社会に大きな刺激を与えると ともに, 地域活動を通して地球的視野の連帯感が培われる。

\section{4. パートナーシップによる活動展開とネットワーク形成}

困 1 は, このようにして形成される, 市民参加システム のプロセスを示すが，その実現には行政や企業等の積極的 な協力と財政支援が不可欠である。この場合, 行政は市民 活動に単なる労㗢の肩代わりを期待するのではなく，その 主体性を尊重し, 裏方で支えることが望まれる。そうあっ てこそ，市民活動はますます活発に展開され，大きな効果 を発揮するようになるのである。

農山村のパートナーとして里山管理や農作業に参加する ことで, 都市住民は心身解放の場や精神的拠り所を得, 健 康づくりや生きがい, 家族や地域の人々とのコミュニケー ションの場を得ることもできる。また, 受験教育では期待 できない子供の環境教育, 人格形成, 創造力の育成等の場 を得ることができ, さらに安心できる食料の入手システム を独自に確保することさえできる。世界的な食料危機が䯚 念されるとき, 食料の自給率が 3 割程度にすぎない我が国 の実状を考慮すると, 都市と農山村との父流による「きづ な」を再構築することは, 安全確保の上からも必要である。

あちろん, 散発的に気楽な余暇活動として訪れる, 都市 住民によ゙れほどの支援が期待できるか危ぶむ気持ちが，農 山村側にあるに違いない。しかし，都市からの来訪者を的 確にコーデイネートするシステムの構築と, 継続参加によ る知識や技術の修得を考えれば，無視できない力となる。 できるだけ多くの人々に，森林管理の充実感やおもしろさ を体験してもらい，はまり込んでもらうことが，より多く の里山や田園の社会的・国民的保全のために必要である。

一連の実践的試みや活動の中から, 場所（里山・田園） の確保と運営組織さえ用意できれば, 参加する市民の潜在 量は相当のあのであることが確認されている。実際に，こ の $4 \sim 5$ 年のうちに全国の都市周辺で, 都市住民による雑 木林の管理, さらにはスギ・ヒノキ林の間伐や枝打ちなど が活発に行われだしている。また森林管理のみならず，今 やその活動は間伐材を利用した炭焼き, 落葉や下草を利用 した稲や野菜の有機栽培など，多様な展開が進みつつある。 しかし, 以上のような都市住民の活動は, 盛んになりつ つあるとはいえ, 多くは未だ地域的なグループ活動の域を 脱しておらず, 参加人口む限られている。それは身近な所 に参加の場所や機会がなく, また都市住民の潜在的な参加 意欲をすくい上げ，農山村につなぐ組織システムも十分に
用意されていないからにほかならない。この方面での我が 国社会の立ち遅れが指摘される所以である。

したがって今後, 英国の全国的な環境保全ボランティア・ トラストである BTCVのように, より広範な人々の参加 要求に対応し, 潜在的な意欲や情熱を励起するシステムを 確立するには，全国の市民活動団体が相互に協力・連携し てネットワークを形成し, 情報や技術, 経験の交換, 活動 プログラムや人材の交流を行うことが必要である。

\section{5.おわりに}

今後, まず都市近郊の里山・田園地域を, 保全緑地等と して積極的に確保し, 開発から保全するととあに, 市民活 動の場として開放することが望まれる。行政と市民とかつ ての農家のパートナーシップによって, 多様な野生生物の 共生する伝統的な里山・田園環境を身近なところに動態保 全するのである。そうして, 市民の自然回帰と楽しみの場, 子供達の自然遊びや環境教育の場とすると同時に, 里山・ 田園管理のリーダー養成の場とする。

図 2 は, 市民参加による保全活動の波及効果を，森林管 理を事例に示したものであり, 今後このような参加・協力 システムの成立と展開により, 豊かな農山村景観と持続的 な国土環境が保全，回復されることを期待したい。

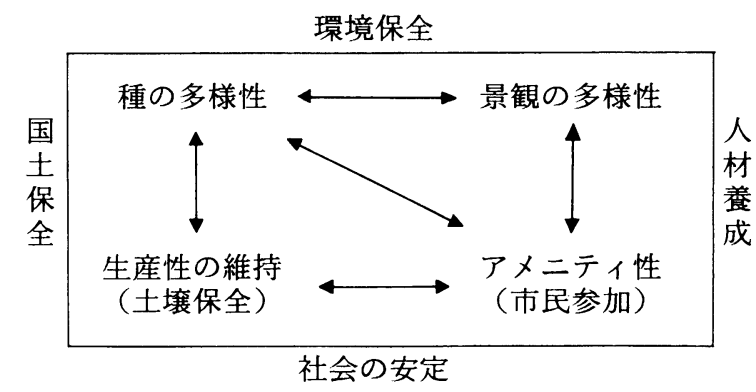

図ー2 市民参加によるエコロジカルな森林環境修復の効果

\section{引用・参考文献}

1 ）重松敏則(1994）：里山・田園景観の現状と課題：公園 緑地 54(6), 8-11

2 ) 重松敏則(1990）: 里山林の保全・管理に対する市民の 参加意欲について：農村計画学会誌 9(1), 6-22

3 ）重松敏則(1996)：里山・田園環境の保全活動をべース とした環境教育と市民参加のシステム開発 : 平成 6 年 度文部省科学研究費 (一般研究 $B$ ) 研究成果報告書 (No. 05454102)

4 ）重松敏則(1997）：里山・田園環境の保全活動をべース とした市民参加のシステムと国際交流 : 農村計画学会 学術研究発表会要旨集, 245-248

5 ）重松敏則(1992)：英国 BTCV の田園景観及び森林生 物環境の保全活動について: 造園雑誌 55(5), 325-330 